\title{
Wastewater use in algae production for generation of renewable resources: a review and preliminary results
}

Omatoyo K Dalrymple ${ }^{1 *}$, Trina Halfhide ${ }^{1}$, Innocent Udom² ${ }^{2}$ Benjamin Gilles², John Wolan², Qiong Zhang ${ }^{1}$ and Sarina Ergas ${ }^{1 *}$

\begin{abstract}
Microalgae feedstock production can be integrated with wastewater and industrial sources of carbon dioxide. This study reviews the literature on algae grown on wastewater and includes a preliminary analysis of algal production based on anaerobic digestion sludge centrate from the Howard F. Curren Advanced Wastewater Treatment Plant (HFC AWTP) in Tampa, Florida and secondary effluent from the City of Lakeland wastewater treatment facilities in Lakeland, Florida. It was demonstrated that a mixed culture of wild algae species could successfully be grown on wastewater nutrients and potentially scaled to commercial production. Algae have demonstrated the ability to naturally colonize low-nutrient effluent water in a wetland treatment system utilized by the City of Lakeland. The results from these experiments show that the algae grown in high strength wastewater from the HFC AWTP are light-limited when cultivated indoor since more than $50 \%$ of the outdoor illumination is attenuated in the greenhouse.

An analysis was performed to determine the mass of algae that can be supported by the wastewater nutrients (mainly nitrogen and phosphorous) available from the two Florida cities. The study was guided by the growth and productivity data obtained for algal growth in the photobioreactors in operation at the University of South Florida. In the analysis, nutrients and light are assumed to be limited, while $\mathrm{CO}_{2}$ is abundantly available. There is some limitation on land, especially since the HFC AWTP is located at the Port of Tampa. The temperature range in Tampa is assumed to be suitable for algal growth year round. Assuming that the numerous technical challenges to achieving commercial-scale algal production can be met, the results presented suggest that an excess of 71 metric tons per hectare per year of algal biomass can be produced. Two energy production options were considered; liquid biofuels from feedstock with high lipid content, and biogas generation from anaerobic digestion of algae biomass. The total potential oil volume was determined to be approximately 337,500 gallons per year, which may result in the annual production of 270,000 gallons of biodiesel when $80 \%$ conversion efficiency is assumed. This production level would be able to sustain approximately 450 cars per year on average. Potential biogas production was estimated to be above $415,000 \mathrm{~kg} / \mathrm{yr}$, the equivalent of powering close to 500 homes for a year.
\end{abstract}

\section{Introduction}

The United States (US) imports about $57 \%$ of the petroleum it consumes. Among all sectors, transportation accounts for $72 \%$ of all petroleum consumption [1]. As energy consumption increases, the US dependence on foreign oil will also increase and compete heavily with the energy demands of rapidly growing economies such

\footnotetext{
*Correspondence: odalrymp@mail.usf.edu; sergas@usf.edu

${ }^{1}$ Civil \& Environmental Engineering Department, University of South Florida, Tampa, FL 33620, USA

Full list of author information is available at the end of the article
}

as China, India and Brazil. This will place tremendous pressure on global oil production and may decrease energy security. In addition, the wide and sustained use of petroleum-based fuels has been implicated as a major cause of increased atmospheric greenhouse gases, which may contribute to global climate change [2]. These challenges have sparked the quest for alternative energy sources to serve as viable replacements to reduce dependence on fossil fuels and improve environmental sustainability. Among the many options, microalgae are receiving enormous attention as a source for the

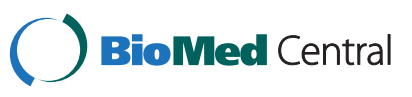


production of biofuels. Model estimates from Pacific Northwest National Laboratory have suggested that algal biofuels (particularly biodiesel) have the potential to meet as much as $17 \%$ of the transportation fuel demand [3]. Microalgae oil production per unit area of land far exceeds other oil crops such as corn, soybean, coconut, and oil palm by as much as 2-3 orders of magnitude [4]. Furthermore, they do not compete for arable land and can be produced year-round in suitable climates. They also grow much faster than traditional crops (doubling time can be as fast as 24 hours) and are likely to recover more quickly from adverse effects [5,6].

Large-scale commercial production of algae, however, is potentially more costly than traditional crop production. Algae cultivation requires significant quantities of energy and water and the use of off-site generated carbon dioxide. One energy intensive process, for example, is the harvesting of the algal biomass, which can account for as much as $30 \%$ of the total cost of production [7-11]. In addition, water and nutrients are among the most critical variables in algal production $[10,12]$. Fortunately, algae can be grown in both fresh water and seawater depending on species, but nutrient costs can be substantial. The main nutritional requirements for algal growth are nitrogen, phosphorous, and a number of micronutrients including potassium [5]. Algae take up these nutrients along with $\mathrm{CO}_{2}$ and produce biomass via photosynthesis. Various combinations of fertilizers maybe used, including common field crop N-P-K fertilizer, but the associated costs can sometimes exceed the value of the final algae products [10].

For algal biofuels to achieve their full potential, inputs to algal cultivation must be inexpensive allowing for the economical mass production of feedstock. A convenient and cheap source of nutrients is municipal, industrial and agricultural wastewaters. Nutrient removal is an important aspect of wastewater treatment because rich nutrient streams discharged into natural water bodies can result in eutrophication. Furthermore, centrate (a nutrient-rich effluent stream from the anaerobic digestion process) is generally recycled to the head of the wastewater treatment plant and can increase the cost and destabilize the overall treatment process due to phosphorus accumulation. Since algae are known to grow in wastewater, a possible synergistic solution is to co-locate and integrate algal production with treatment of nutrient-rich wastewater and utilization of $\mathrm{CO}_{2}$ from power plant flue gas. This approach essentially reduces the cost of algal production, while preventing eutrophication and mitigating $\mathrm{CO}_{2}$ emissions [13-16].

Florida, and particularly the Tampa Bay area, has been identified as an ideal location for the development of algal feedstock and biofuel production because it receives significant sunshine, and demonstrates a relatively uniform seasonal evaporation loss compared to many other areas of the country [3]. The latter is particularly important for open pond cultivation systems that lose significant amounts of water via evaporation. In this study, wastewater use for algae production is reviewed, particularly for renewable energy generation. A preliminary assessment of the potential to produce algal feedstock from wastewater is presented for two Tampa Bay cities. These include the City of Tampa and the City of Lakeland. All the wastewater from the City of Tampa is treated at the Howard F. Curren Advanced Wastewater Treatment Plant (HFC AWTP). HFC AWTP has a designed average daily flow capacity of 96 million gallons per day (MGD) and employs high-purity oxygen aeration for biochemical oxygen demand (BOD) removal followed by nitrification and denitrification. Lakeland's municipal wastewater is treated by two traditional wastewater treatment plants and the secondary effluent is released into a 1,400-acre wetland treatment system (WTS) to achieve permissible nutrient reduction levels. The average daily flow rate into the wetland is 5.2 MGD. The WTS consist of a series of wetland cells connected by engineered discharged structures. Effluent from the WTS is discharged to the Alafia River. A wide cross-section of freshwater algal species thrives in the WTS.

Most of the electricity supplied to the Bay Area comes from Tampa Electric Company (TEC), which has a power plant located about 15 miles south of the Lakeland WTS and another plant across from the HFC AWTP. Together, these two power plants emit approximately 5.5 million metric tons of $\mathrm{CO}_{2}$ annually. Further, to lessen the burden on scarce freshwater resources, TEC and the City of Lakeland entered into a reclaimed water agreement in 2009 that allows TEC to use reclaimed effluent from the WTS commencing at the end of 2012. TEC will install a water treatment system to ensure that the effluent meets its cooling water standards.

The location of these facilities presents a potentially viable opportunity to explore synergy for algal feedstock production using wastewater and industrial $\mathrm{CO}_{2}$. A preliminary assessment was made to determine the quantity of algal feedstock that can be generated. The analysis was guided by experimental work on the growth of algae in enclosed bench-scale photobioreactors. The aim was to assess algae growth rate, nutrient uptake and lipid production using anaerobic digestion centrate from HFC AWTP and the Lakeland WTS.

\section{Experimental methods}

\section{Inoculum collection and scale-up}

Wild-type algae were harvested from a secondary clarifier at the HFC AWTP in Tampa, Florida. Samples were transferred to 1 - $\mathrm{L}$ flasks and bubbled with $2 \% \mathrm{CO}_{2}$ in air during an 18-hr light/dark cycle under artificial light 
conditions of $310 \mu \mathrm{mol} \mathrm{m} \mathrm{m}^{-2} \mathrm{sec}^{-1}$. Anaerobic digestion sludge centrate from the same facility was used as the scale-up medium after removal of suspended matter with a filter cloth. There were no nutrient additions to the centrate. Inoculum was grown until the culture biomass was $2 \mathrm{~g}$ dry wt $\mathrm{L}^{-1}$ as determined by total suspended solid (TSS) analysis with $5 \mathrm{~mL}$ algae suspension according to the standard method [13]. University of Florida Environmental Biotechnology Laboratory analyzed samples and determined that the main algal species were Chlorella sp. and Scenedesmus sp.

\section{Photobioreactor setup and operation}

The algae cultivation setup consisted of three tubular polyethylene photobioreactors (obtained from the Norwegian University of Life Sciences, Norway), which were housed in a greenhouse at the Botanical Gardens of the University of South Florida in Tampa, Florida. Figure 1 shows the setup of the photobioreactors, which began operation in February 2011. The reactors were $237.13 \mathrm{~cm}$ high with a diameter of $12.32 \mathrm{~cm}$. They were each operated at a volume of 7 liters. Air containing $2 \% \mathrm{CO}_{2}$ was bubbled through the reactor using coarse bubble diffusers to provide inorganic carbon for photoautotrophic growth, as well as mixing. The gas flow rate was maintained at $0.5 \mathrm{~L} \mathrm{~min}^{-1}$. The reactors were operated on a semi-continuous basis with a mean cell retention time of 7 days.

Each day, $1 \mathrm{~L}$ of the reactor volume was replaced with centrate collected from the HFC AWTP. The nutrient content of the centrate was analyzed prior to feeding the reactors. A data-logger (Onset ${ }^{\circledR} \mathrm{HOBO}$ U12) was used to record irradiance, ambient temperature, culture temperature and relative humidity every 15 minutes.

A 1-L batch reactor was also operated with wetland water from the City of Lakeland WTS. The WTS contained a native population of algae, whose diversity was previously analyzed by GreenWater CyanoLab (Palatka, FL) and shown to include Bacillariophyta, Chlorophyta and Cyanobacteria groups. Air with $2 \% \mathrm{CO}_{2}$ was fed to the reactor in like manner as the plastic reactors. A lownutrient media was maintained by semi-continuous addition of $50 \mathrm{~mL}$ of $22.5 \mathrm{mg} \mathrm{L}^{-1} \mathrm{~K}_{2} \mathrm{HPO}_{4}$ and 60.71 $\mathrm{NaNO}_{3}$ to the batch reactor. The batch was operated for 3 weeks. Similar nutrient analyses were performed as previously described. All nutrients used in the study were obtained from Sigma Aldrich (St. Louis, MO).

\section{Pretreatment and wastewater characterization}

Anaerobic digestion sludge centrate was collected once weekly and filtered with a fabric to remove coarse bio-solids. Total nitrogen (TN), ammonia and total

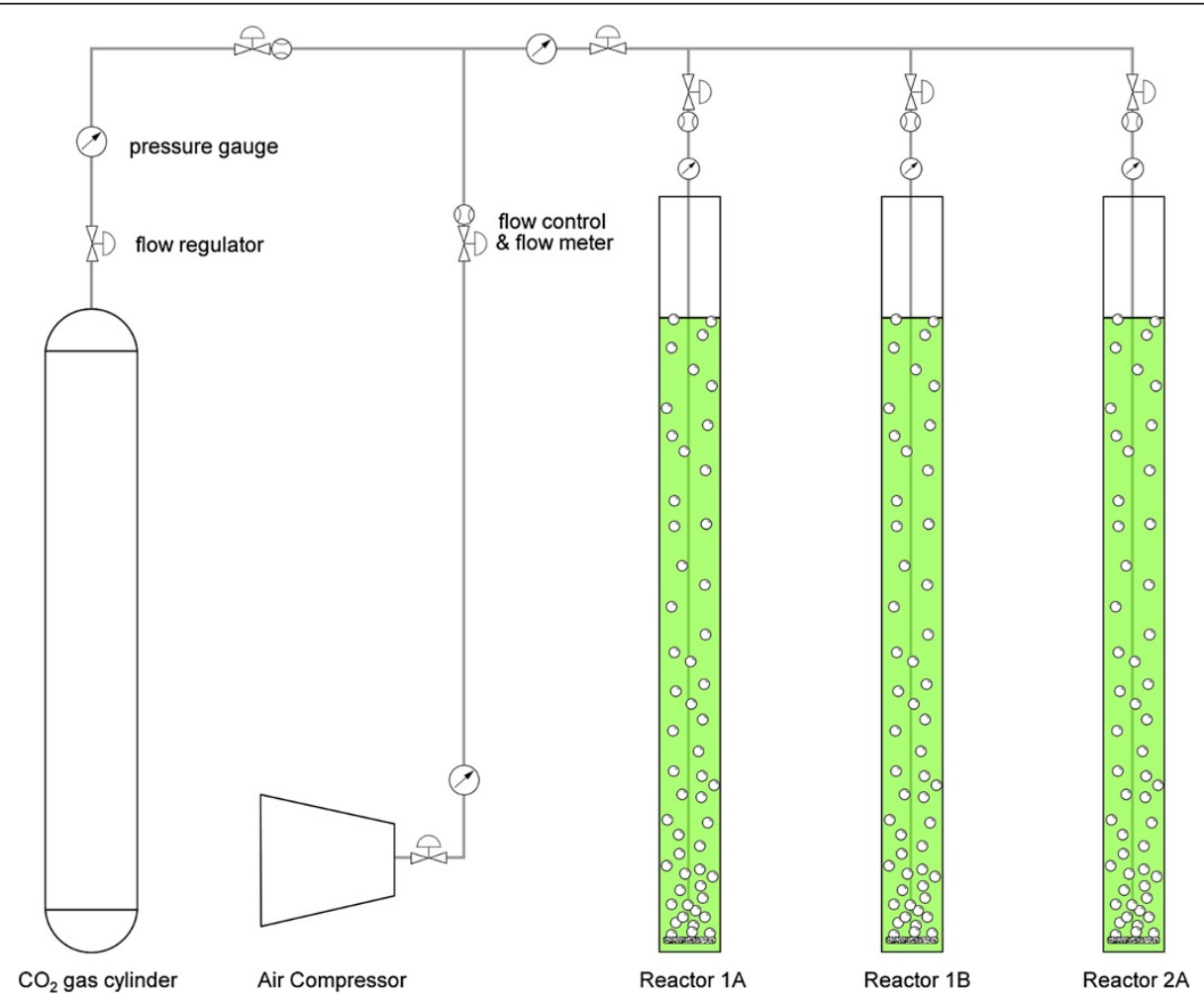

Figure 1 Schematic of bench-scale tubular plastic photobioreactors located in greenhouse at the University of South Florida, Tampa, FL and operated under natural light conditions. 
phosphorous (TP) content were determined. To avoid death of the culture when the centrate nutrient content was very low, the $\mathrm{TN}$ concentration in the feed was maintained between $200-250 \mathrm{mg} \mathrm{L}^{-1}$ by addition of $(\mathrm{NH} 4)_{2} \mathrm{SO}_{4}$. Table 1 provides details of the nutrient content of the centrate.

\section{Biomass and nutrient monitoring}

Measurements of TSS and $\mathrm{pH}$ were performed daily. Nutrient removal analyses were performed every week for TN, ammonia $\left(\mathrm{NH}_{3}\right)$, nitrate $\left(\mathrm{NO}_{3}{ }^{-}\right)$, TP and chemical oxygen demand (COD) according to Standard Methods [17]. TSS was determined by filtering a $5-\mathrm{mL}$ algae suspension followed by drying in an oven for 24 hours.

\section{Lipid content analysis}

The algal lipid content was determined according to the method by Bligh and Dryer [18]. A sample of algae suspension was centrifuged at 3,800 rpm for 10 minutes to obtain a concentrated algae paste. The dry weight $\left(w_{d}\right)$ of the paste was determined gravimetrically after drying at $60^{\circ} \mathrm{C}$. A 2-mL sample of algae solution was mixed with $4 \mathrm{~mL}$ of a 2:1 methanol/chloroform solution in a glass vessel. The suspension was left for 24 hours. Thereafter, $1 \mathrm{~mL}$ of chloroform was added and the solution was mixed on a vortex for $1 \mathrm{~min} .2 \mathrm{~mL}$ of water was then added and the mixture was again agitated for 2 min. The layers were separated by centrifugation at $2,000 \mathrm{rpm}$ for $10 \mathrm{~min}$. The lower layer was extracted with a glass syringe and filtered through a Whatman no. 1 filter into a previously weighed glass vessel $\left(w_{1}\right)$. The solvent was dried in a water bath at $98^{\circ} \mathrm{C}$ and the vessel was weighed again $\left(w_{2}\right)$ to obtain the lipid content of the sample as;

$$
\text { lipid content }=\frac{W_{2}-W_{1}}{W_{d}} \times 100 \%
$$

\section{Results}

\section{Light conditions}

The experiment was conducted in the summer from May 7, 2011 to September 30, 2011 in greenhouse conditions at the University of South Florida, Tampa, Florida. An evaporative cooling system kept peak daily ambient temperatures in the greenhouse below $40^{\circ} \mathrm{C}$. Figure 2 shows

Table 1 Nutrient content of centrate used as growth media for mixed algae species

\begin{tabular}{ll}
\hline Parameter & Range \\
\hline Total nitrogen & $200-250 \mathrm{mg} \mathrm{L}^{-1}$ \\
\hline Total phosphorous & $2-75 \mathrm{mg} \mathrm{L}^{-1}$ \\
\hline Ammonia & $100-250 \mathrm{mg} \mathrm{L}^{-1}$ \\
\hline
\end{tabular}

the instantaneous PAR and daily integrated insolation for the period of cultivation. Daily insolation was highest in the early summer months (May-July) averaging $12 \mathrm{~mol}$ photons $\mathrm{m}^{-2} \mathrm{~d}^{-1}$. During the latter period of cultivation (August-September), mean daily insolation fell to $10 \mathrm{~mol}-$ photons $\mathrm{m}^{-2} \mathrm{~d}^{-1}$. Daily peak instantaneous PAR was $c a$. $600 \mu$ mol-photons $\mathrm{m}^{-2} \mathrm{~s}^{-1}$.

\section{Temperature and $\mathrm{pH}$}

Culture temperature for the duration of the experiment is shown in Figure 3. Mean culture temperature was $29.2^{\circ} \mathrm{C}$. Peak daily culture temperatures remained mostly below $40^{\circ} \mathrm{C}$. Diurnal temperature changes were on average $13^{\circ} \mathrm{C}$ for the period of cultivation. Changes in $\mathrm{pH}$ are shown in Figure 4 and were more variable ranging between 6 and 9. There was an excursion of $\mathrm{pH}$ above 9 from days 20 to 30 .

\section{Biomass development and production rates}

Microalgae biomass development in the photobioreactors is shown in Figure 5. Standing biomass concentration during the first 80 days of operation was $0.75 \mathrm{~g}$ dry wt $\mathrm{L}^{-1}$. Air diffusers were replaced on day 80 and resulted in improved mixing and an associated doubling in the standing biomass. Steady state dry biomass concentration remained below $2 \mathrm{~g}$ dry wt $\mathrm{L}^{-1}$. Photobioreactor areal production $P\left(\mathrm{~g}\right.$ dry wt $\left.\mathrm{m}^{-2} \mathrm{~d}^{-1}\right)$ was calculated based on illuminated surface area $A\left(\mathrm{~m}^{-2}\right)$ according to equation 2 .

$$
P=\frac{Q C}{A}
$$

where $\mathrm{Q}$ is the daily flow rate $\left(\mathrm{L} \mathrm{d}^{-1}\right)$ and $\mathrm{C}$ the algae biomass concentration ( $g$ dry wt $\mathrm{L}^{-1}$ ). The mean production rate for the first 80 days was $2.5 \mathrm{~g}$ dry wt $\mathrm{m}^{-2} \mathrm{~d}^{-1}$, which increased to $4.5 \mathrm{~g}$ dry wt $\mathrm{m}^{-2} \mathrm{~d}^{-1}$ for the last 45 days. The maximum sustained production rate was $7 \mathrm{~g}$ dry wt $\mathrm{m}^{-2} \mathrm{~d}^{-1}$ for one week. The areal productivity of the batch culture with Lakeland WTS algae was approximately $0.5 \mathrm{~g}$ dry wt $\mathrm{m}^{-2} \mathrm{~d}^{-1}$ (data not shown). For the tubular reactors, the most active growth period occurred from days 87-100, after the diffusers were replaced.

\section{Nutrient uptake}

The fraction of nutrients taken up is illustrated in Figure 6. Nutrient uptake was determined from the difference between filtered and unfiltered samples. The latter was diluted before analysis. TN uptake was just below $60 \%$, while $72 \%$ ammonia was taken up. Phosphorous removal was greater than $85 \%$. 

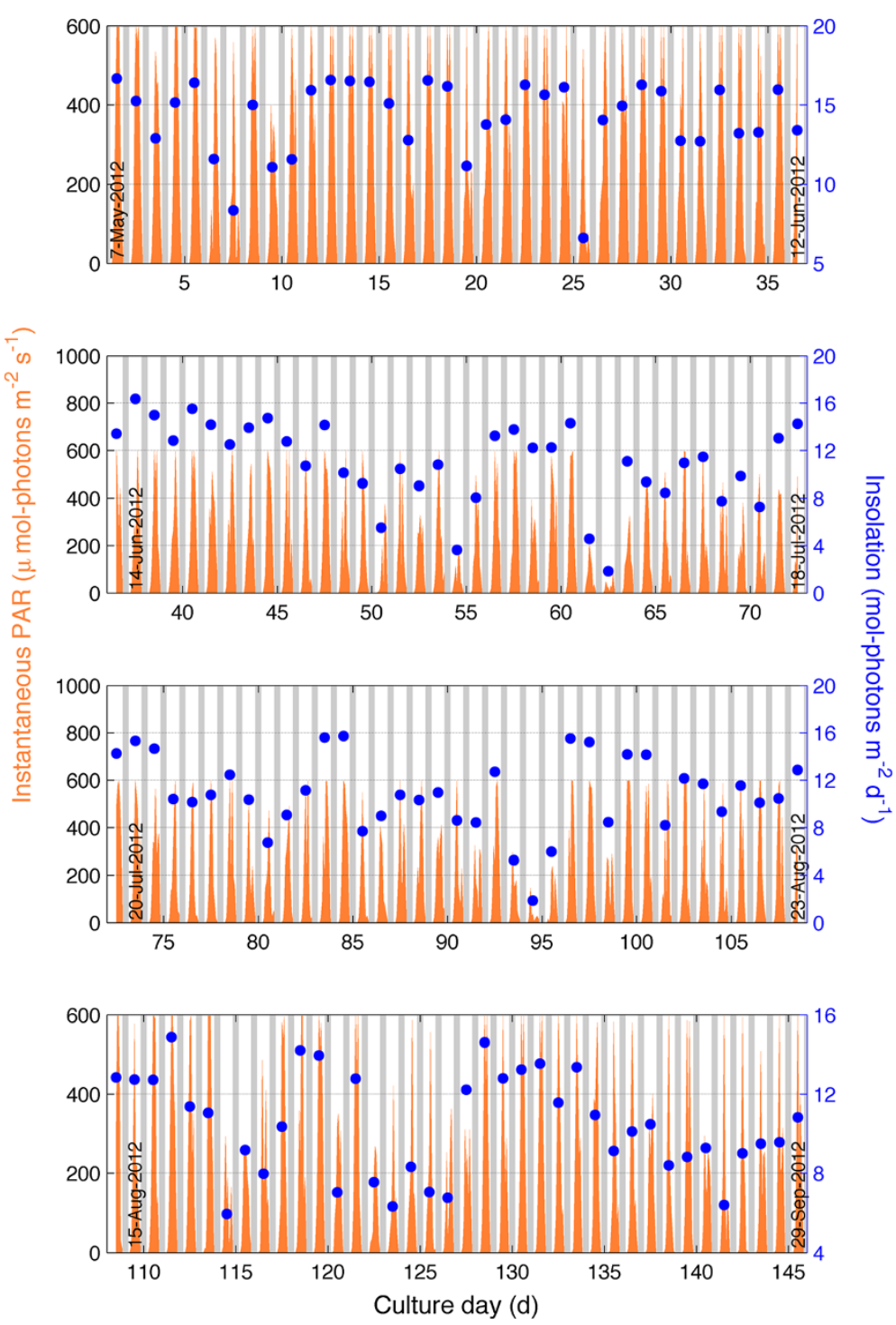

Figure 2 Instantaneous PAR and daily insolation during cultivation period from May to September 2011. Data was recorded in the greenhouse at University of South Florida, Tampa, FL. Daily insolation was obtained by integrating PAR over day.

\section{Lipid content}

Algae grown on the high strength centrate had very low lipid content $(<10 \%)$ compared to the $65 \%$ lipid content of Lakeland WTS algae consortium.

\section{Discussion}

\section{Algae biomass production potential from wastewater resources}

This study was conducted to assess the potential of cultivating algae using wastewater as a nutrient medium. The consortium of algal species, including Scenedesmus sp. and Chlorella sp. grew favorably on anaerobic sludge centrate from the HFC AWTP. There was relatively high nutrient uptake for phosphorous and ammonia. Total nitrogen uptake was much lower because organic nitrogen was most likely not assimilated by the culture. The mean productivity obtained for the entire cultivation period was $3.3 \pm 1.5 \mathrm{~g}$ dry wt $\mathrm{m}^{-2} \mathrm{~d}^{-1}$. These results are similar to Woertz et al. [19] who report an algae production rate of $3 \mathrm{~g}$ dry wt $\mathrm{m}^{-2} \mathrm{~d}^{-1}$ for Chlorella sp. grown on wastewater. Li et al. [20] report a biomass production rate of $13 \mathrm{~g}$ dry wt $\mathrm{m}^{-2} \mathrm{~d}^{-1}$ for algae grown on centrate. Their results showed that by the end of a 14-day batch culture 94\% ammonia, 89\% TN and 81\% TP was removed. Their system was continuously operated at $50 \%$ daily harvesting rate, compared to $14 \%$ used in this study. Zhou et al. [21] also grew algae on full strength anaerobic sludge centrate and obtained a biomass production rate of 12.8 g dry wt $\mathrm{m}^{-2} \mathrm{~d}^{-1}$. The lipid content reported by Li et al. [20] was ca. $11 \%$, similar to these results. This is a 


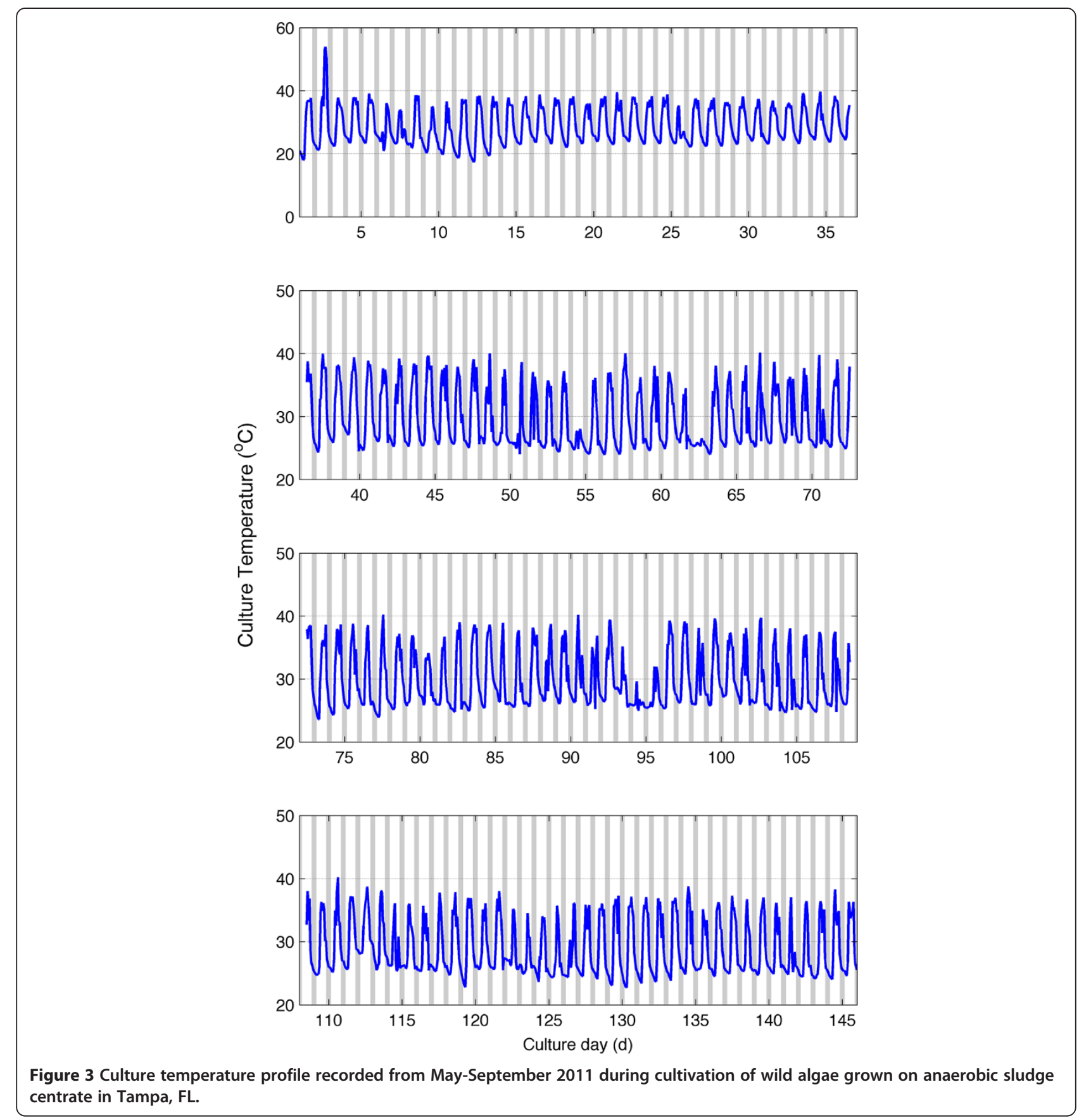

downside of growing algae, especially Chlorella sp., in high strength nitrogen media. The caloric content which is linked to lipid production is significantly reduced [22]. In general, high lipid content is achieved when the organisms are "starved" of nitrogen $[4,22,23]$.

\section{Potential application to large-scale algal production}

Photobioreactor optimization can potentially increase biomass production, as observed from improving only air bubbling in this study. Improved air delivery was achieved by changing from spherical to cylindrical ceramic diffusers, resulting in better mixing. Work by Richmond [24], Richmond and Zou [25] and Qiang and Richmond [26] indicates that highly productive and efficient enclosed algal systems can be obtained by optimizing cell density and mixing rate in relation to photon flux density, particularly when nutrients are not limited. In addition, better aeration promotes increased mass transfer allowing for the removal of oxygen, which can become inhibiting at high concentrations [19]. 


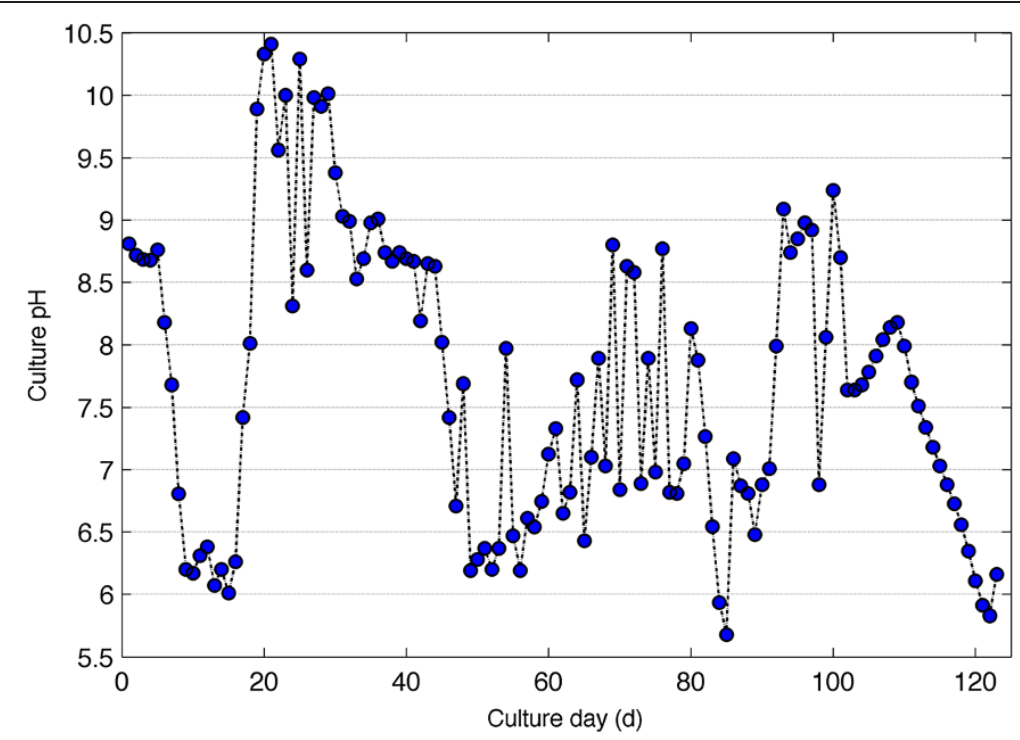

Figure 4 Daily culture pH for algae grown on anaerobic sledge centrate from the Howard F. Current Advanced Wastewater Treatment Plant, Tampa, FL. pH measurement was taken once a day and therefore do not capture any diurnal variations.

However, there are limits to the photosynthetic conversion of sunlight energy into algal biomass in largescale outdoor cultures. Under light-limited growth, there is an upper limit for light conversion efficiency of a large-scale culture. In practice, this usually translates to

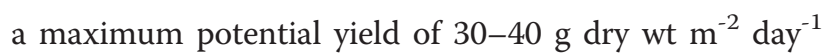
under ideal outdoor sunlight conditions for short periods and considerably less for longer durations. This indicates that the non-optimized operation in this preliminary assessment was able to achieve $10 \%$ of the maximum.
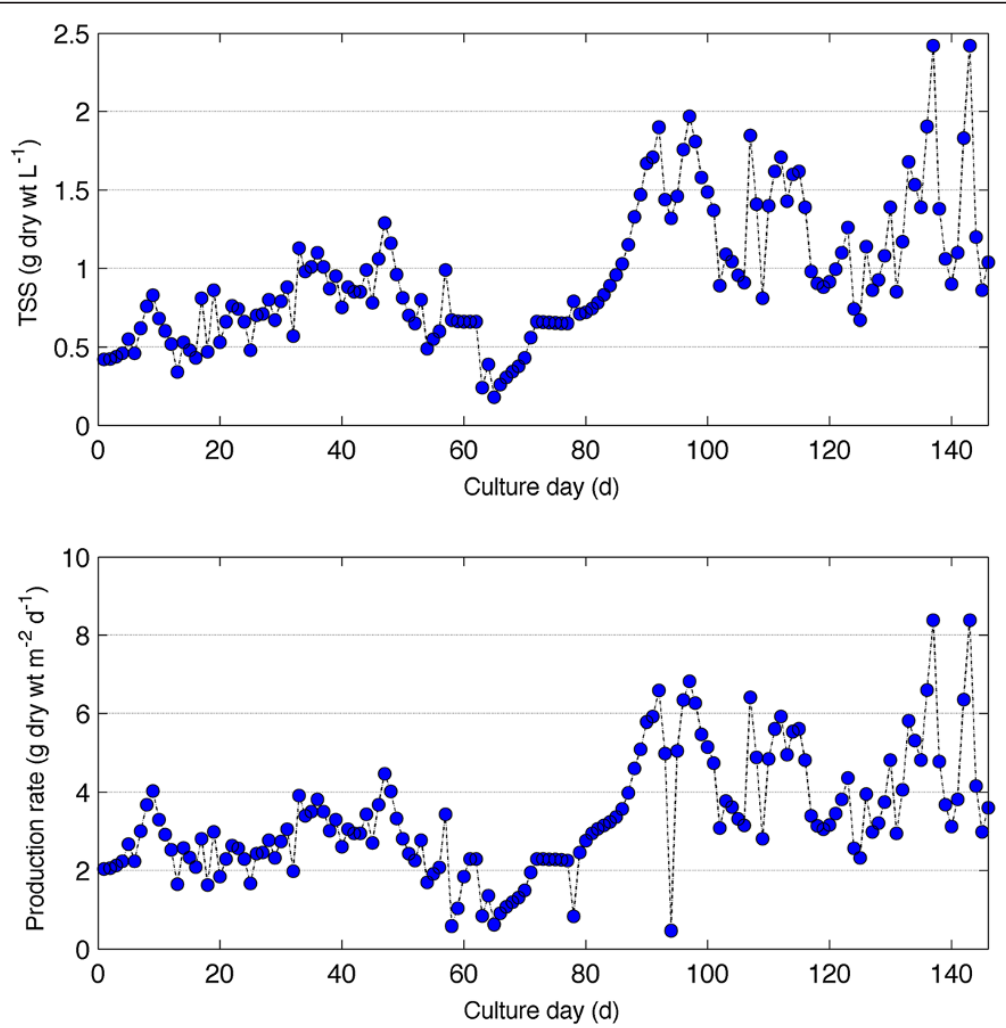

Figure 5 Growth (top) and areal biomass productivity (bottom) of mixed algal species grown on anaerobic sludge centrate for the period May to September 2011 in Tampa, FL. Productivity calculations are based on reactor illuminated surface area. 


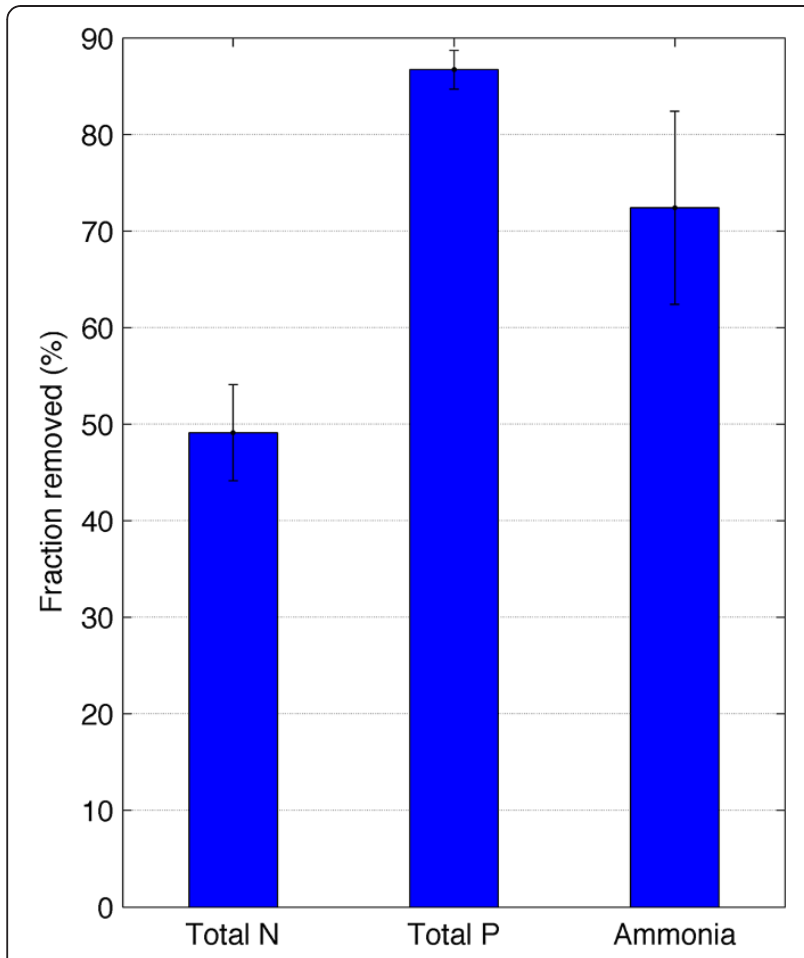

Figure 6 Fraction of nutrients taken up by mixed algae species grown in enclosed photobioreactor from centrate medium. Nutrient uptake was determined from the difference between filtered and unfiltered samples.
However, the cultures were grown under conditions of reduced light. It is possible to cultivate algae outdoor and improve light utilization through vertical reactor orientation, while keeping peak temperature down due to mutual shading of reactors [27].

Production in high rate algal ponds (HRAP) is possible and has shown commercial production rates as high as $40 \mathrm{~g}$ dry wt $\mathrm{m}^{-2} \mathrm{~d}^{-1}$ [28]. Craggs et al. [29] provide a good summary of production in HRAP. There is a wide variability of production rates achieved based on wastewater source, type, location and culture conditions. Algae growth in HRAPs has also been shown to achieve greater than $75 \%$ nutrient removal [30]. Production was shown to improve with $\mathrm{CO}_{2}$ addition from 10.6 to 15.2 g dry wt $\mathrm{m}^{-2} \mathrm{~d}^{-1}$. Li et al. [20] and Zhout et al. [21] scaled up their wastewater-grown algal with 25-L BIOCOIL reactors and obtained net biomass productivity of 13 and $12.8 \mathrm{~g}$ dry wt $\mathrm{m}^{-2} \mathrm{~d}^{-1}$ respectively.

The basic principles and a schematic behind the operation for algal integration with wastewater facilities and power plants are shown in Figure 5 and Figures 7 and 8. While the challenges associated with algal harvesting, species control, and fuel conversion must be solved for large-scale production, the harvestable yields of algal biomass (g dry wt $\mathrm{m}^{-2} \mathrm{~d}^{-1}$ ) helps to determine the potential of algal systems for energy and fuel production. These yields depend largely on nutrient availability and lighting conditions. In this section, the nutrient removal efficiency and observed areal productivity for the benchscale photobioreactors are used to determine the size of the algae production facility.

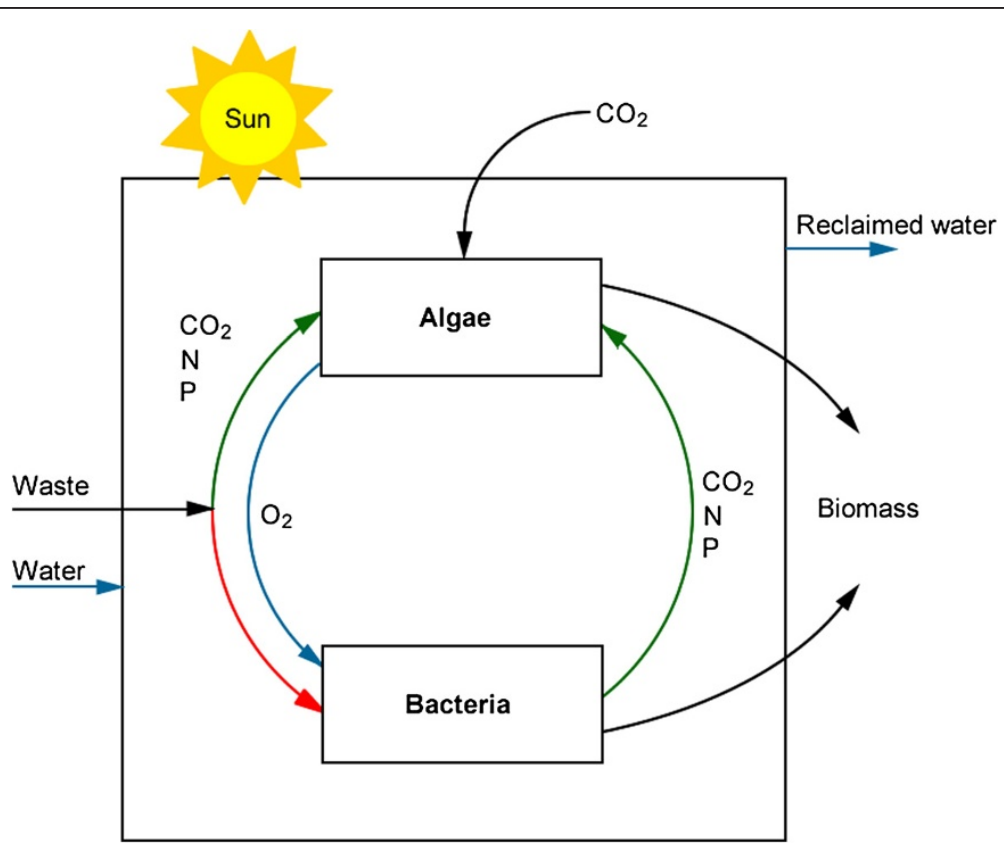

Figure 7 Basic operation principles for the algal production integration with wastewater treatment [10]. 


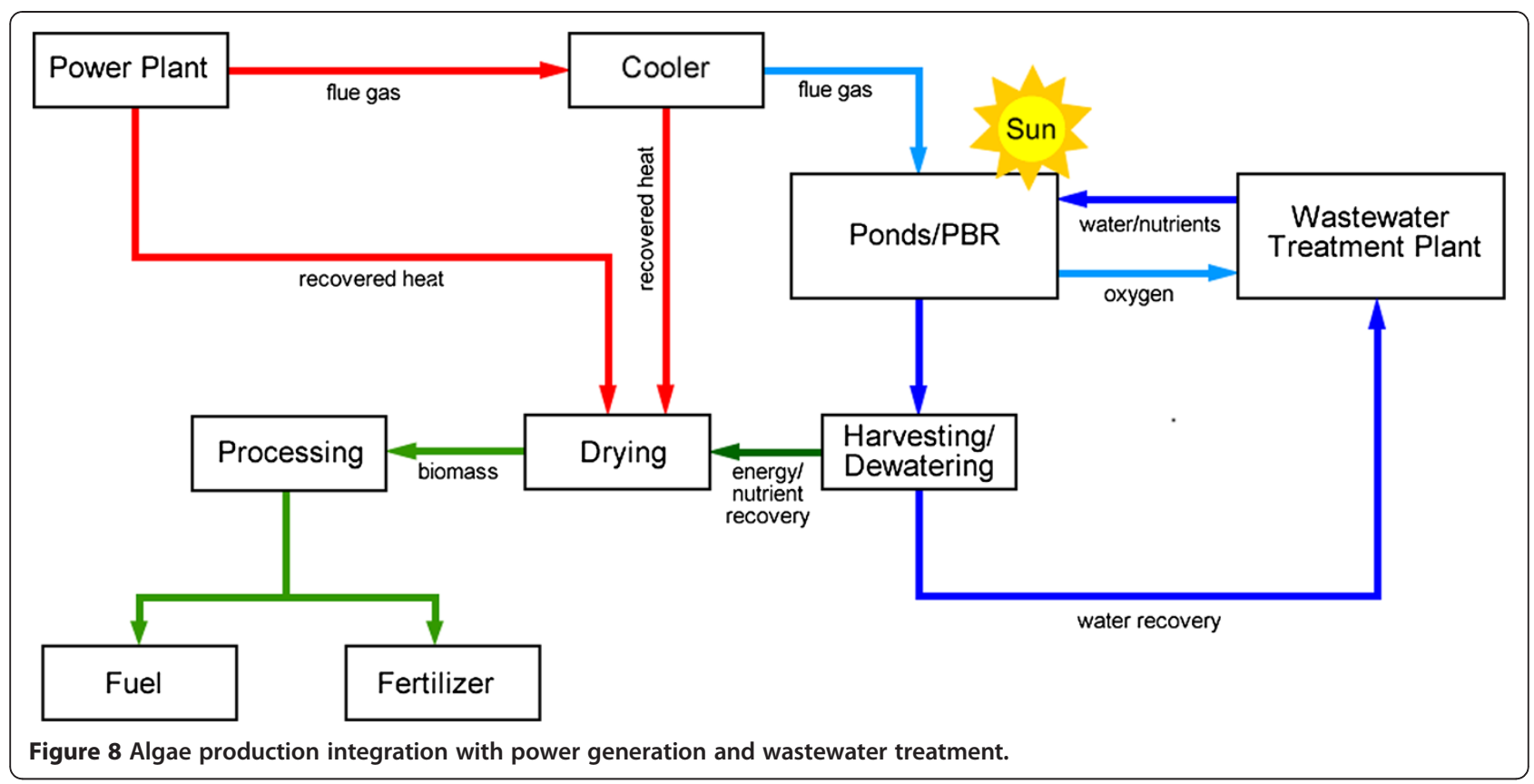

Microalgae biomass results mainly from photosynthesis, which utilizes inorganic compounds (including $\mathrm{CO}_{2}$ ). In simple terms, algal biosynthesis can be described by the following chemical equations where ammonium and nitrate are the nitrogen sources respectively [31,32];

$$
\begin{aligned}
& 16 \mathrm{NH}_{4}^{+}+92 \mathrm{CO}_{2}+92 \mathrm{H}_{2} \mathrm{O}+14 \mathrm{HCO}_{3}^{-} \\
& \quad+\mathrm{HPO}_{4}^{2-} \stackrel{h v}{\rightarrow} \mathrm{C}_{106} \mathrm{H}_{263} \mathrm{O}_{110} \mathrm{~N}_{16} \mathrm{P}+106 \mathrm{O}_{2} \\
& 16 \mathrm{NO}_{3}^{-}+124 \mathrm{CO}_{2}+140 \mathrm{H}_{2} \mathrm{O} \\
& \quad+\mathrm{HPO}_{4}^{2-} \stackrel{h v}{\rightarrow} \mathrm{C}_{106} \mathrm{H}_{263} \mathrm{O}_{110} \mathrm{~N}_{16} \mathrm{P}+138 \mathrm{O}_{2} \\
& \quad+18 \mathrm{HCO}_{3}^{-}
\end{aligned}
$$

In the above equations, the chemical formula $\mathrm{C}_{106} \mathrm{H}_{263}$ $\mathrm{O}_{110} \mathrm{~N}_{16}$ represents algal biomass [32]. According to the stoichiometry, $1 \mathrm{~g}$ of ammonia-nitrogen $\left(\mathrm{NH}_{3}-\mathrm{N}\right)$ or nitrate-nitrogen $\left(\mathrm{NO}_{3}^{-}-\mathrm{N}\right)$ produces about $15.8 \mathrm{~g}$ of biomass and consumes 18.1 and 24.34 $\mathrm{g}$ of $\mathrm{CO}_{2}$ in the process, respectively. In addition to nutrient availability, algal biomass production also depends on light energy $(h v)$. In the absence of nutrient limitation, photosynthesis increases with increasing irradiance until the maximum algal growth rate is attained as described my
Michaelis-Menten kinetics [24-26]. A condition known as photoinhibition can occur when the irradiance is increased beyond the saturation point resulting in damage to algal light receptors and a decrease in the photosynthetic rate and productivity [24,25].

The total amount of algal biomass produced may be estimated by considering the total flows of nitrogen. Nitrogen is assumed to be the limiting nutrient since phosphorous is generally considered to be an abundant nutrient in Tampa due to the numerous phosphate deposits. The annual production estimates for algal production based on the concentrations of nitrogen in wastewater from the HFC AWTP and the Lakeland WTS are shown in Table 2. These calculations include the average flow rate of water passing through each plant. The required area to facilitate production is estimated based on the observed productivity for algae grown on centrate and the Lakeland WTS water. The growth rate and lipid production for algae grown on wastewater with moderate nitrogen levels ( 30 mg/L) were adopted from Woertz et al. [19] as $3 \mathrm{~g}$

\begin{tabular}{|c|c|c|c|c|c|c|c|}
\hline Description & Source & $\begin{array}{c}\text { Flow rate } \\
\text { (MGD) }\end{array}$ & $\begin{array}{c}\text { Nitrogen } \\
\left(\mathrm{mg} \mathrm{L}^{-1}\right)\end{array}$ & $\begin{array}{l}\text { Algae biomass } \\
\text { (tons } \mathrm{yr}^{-1} \text { ) }\end{array}$ & $\begin{array}{l}\mathrm{CO}_{2} \text { consumed } \\
\left.\text { (tons } \mathrm{yr}^{-1}\right)\end{array}$ & $\begin{array}{c}\text { Indoor area } \\
\text { (ha) }\end{array}$ & $\begin{array}{c}\text { Outdoor area } \\
\text { (ha) }\end{array}$ \\
\hline Wastewater & HFC AWTP & 3.0 & 30 & 1,965 & 3,026 & 179 & 179 \\
\hline Centrate & HFC AWTP & 0.5 & 427 & 4,660 & 7,179 & 182 & 80 \\
\hline Wastewater & WTS & 5.0 & 10 & 1,091 & 1,681 & 598 & 598 \\
\hline Total & & & & 7,716 & 11,889 & 959 & 857 \\
\hline
\end{tabular}
dry wt $\mathrm{m}^{-2} \mathrm{~d}^{-1}$ and $30 \%$ lipids by dry weight respectively.

Algal production is restricted by available land close to the HFC AWTP. Approximately 200 hectares of suitable

Table 2 Potential biomass production estimates for algae grown on wastewater nutrients in the Tampa Bay area, FL 
Table 3 Annual biofuel production estimates derived from algae growth in wastewater nutrients in the Tampa Bay area, FL

\begin{tabular}{|c|c|c|c|c|}
\hline Description & Source & Algae biomass (tons $\mathrm{yr}^{-1}$ ) & Biofuel (gal $\mathrm{yr}^{-1}$ ) & Total revenue (US\$ $\left.\mathrm{yr}^{-1}\right)^{1}$ \\
\hline Wastewater & HFC AWTP & 1,965 & 112,833 & 451,332 \\
\hline Wastewater & WTS & 1,091 & 156,712 & 626,848 \\
\hline Total & & 3,056 & 269,545 & $1,078,180$ \\
\hline
\end{tabular}

${ }^{1}$ Biodiesel cost $\$ 4.05$ per gal taken from the Center for Agricultural and Rural Development (CARD), http://www.card.iastate.edu/research/bio/tools/hist_bio_gm. aspx, lowa State University, Ames, lowa.

land area is available onsite and is located within close vicinity to where centrate is generated. Therefore, the flow rate has been chosen to reflect the land restriction for the indoor production. It is assumed that algae grown on moderate and low strength nutrient are nutrient limited and hence, their productivities are not affected by increasing light beyond a certain value. However, for algae grown on high strength centrate, the outdoor production area can be reduced since the algae are not nutrient limited.

\section{Energy production and revenue potential Liquid biofuels}

For biofuel production, algae need to have a lipid content exceeding 20\% [10], some researchers even suggest $40 \%$ [33]. This means that high strength wastewater would not be suitable for cultivating algae for lipid production. Realistically, the best algae for lipid production are those from the Lakeland WTS or algae grown on low strength wastewater. Usable lipids were assumed to be $20 \%$ and $50 \%$ of the algae dry wt. for moderate strength wastewater and low strength pond water, respectively. An algal oil-to-biofuel conversion efficiency of $80 \%$ was used, which is similar to that obtained for vegetable oil [34]. The biofuel potential for the various algae are shown in Table 3. The total potential volume of biofuel obtained is approximately 269,545 , which can, on average, fuel 450 cars per year (assuming 15,000 miles $\mathrm{yr}^{-1}$ with an average of 25 miles per gallon).

\section{Biogas generation}

Algae biomass may be anaerobically digested to produce methane, especially biomass which may be considered unsuitable for liquid biofuel production due to low lipid content. The stoichiometric relationships for this process are illustrated in Equation (5), which were developed from half reactions assuming that ammonia is the nitrogen source [35]. The fraction of electrons towards energy production $\left(f_{e}\right)$ was estimated to be 0.89 based on the work by Yuan et al. [36].

$$
\begin{aligned}
& \mathrm{C}_{106} \mathrm{H}_{263} \mathrm{O}_{110} \mathrm{~N}_{16}+6.672 \mathrm{H} 2 \mathrm{O} \\
& \rightarrow 13.668 \mathrm{NH}_{4}^{+}+33.502 \mathrm{CO}_{2}+47.170 \mathrm{CH} 4 \\
& +2.332 \mathrm{C}_{5} \mathrm{O}_{2} \mathrm{H}_{7} \mathrm{~N}+13.668 \mathrm{HCO}_{3}^{-}+\mathrm{HPO}_{4}^{2-}+2 \mathrm{H}^{+}
\end{aligned}
$$

According to equation 5, 1 mole of algae biomass produces 47.17 moles of methane. However, previous research has shown that algal biomass is not particularly easy to digest having a biogas yield of $29.5 \%$ [36,37]. Therefore, $1 \mathrm{~g}$ of algae dry wt. is estimated to generate $62.7 \mathrm{mg}$ methane. The estimated production of biogas and the derived energy are shown in Table 4 assuming that the energy content of methane is $55 \mathrm{MJ} \mathrm{kg}^{-1}$ for the HFC AWTP.

The above calculations assumed that the total production of algae goes toward digestion. It is also possible to extract lipids and attempt to derive biogas from spent biomass. The combination of algae production on the wastewater nutrient sources shows the potential for energy generation that can power close to 500 homes.

\section{Conclusions}

This work shows that there are important benefits to be derived from integrating algal production systems with nutrient-rich waste streams. The feedstock potential of the HFC AWTP and the Lakeland WTS is estimated to be approximately 71 tons $\mathrm{ha}^{-1} \mathrm{yr}^{-1}$ of algal biomass, $270,000 \mathrm{gal} \mathrm{hr}^{-1}$ of liquid biofuel, and 415,000 $\mathrm{kg} \mathrm{yr}^{-1}$ of methane. Renewable energy derived from algae will play a significant role in providing energy security while important services such as water treatment can be syner-

\begin{tabular}{|c|c|c|c|c|c|}
\hline Description & Source & Algae biomass (tons $\mathrm{yr}^{-1}$ ) & Biogas production $\left(\mathrm{kg} \mathrm{yr}^{-1}\right)$ & 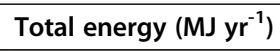 & Households powered $^{1}$ \\
\hline Wastewater & HFC AWTP & 1,965 & 123,215 & $6,776,838$ & 144 \\
\hline Centrate & HFC AWTP & 4,660 & 292,294 & $16,076,165$ & 342 \\
\hline Total & & 6,625 & 415,509 & $22,853,003$ & 486 \\
\hline
\end{tabular}
gistically achieved by these systems. Even though the

Table 4 Biogas production estimates for anaerobic digestion of algae biomass grown on wastewater nutrients

\footnotetext{
${ }^{1}$ Assuming average energy consumption of $653 \mathrm{kWh}$ per month and thermal efficiency of natural gas turbine of $60 \%$ with waste heat recovery.
} 
analysis has been preliminary, it shows that there is good potential for algal feedstock production in the Tampa Bay area. However, there are many important factors to be considered to assess whether algal production systems would be competitive. These include analysis of energy and cost associated with harvesting and extraction for example. It is hoped that with further research many of these challenges can be overcome.

\section{Competing interests}

The authors declare that they have no competing interests.

\section{Authors' contributions}

OKD, TH, IU and BG designed, constructed and operated the photobioreactors and carried out all algae and nutrient analysis related to the centrate studies OKD and TH conducted the studies based on the Lakeland algae samples, carried out lipid analysis and drafted the manuscript. SE, JW and QZ were co-PIs on this project and advised the research assistants on this project. All authors read and approved the final manuscript.

\section{Author details}

${ }^{1}$ Civil \& Environmental Engineering Department, University of South Florida, Tampa, FL 33620, USA. ${ }^{2}$ Chemical \& Biomedical Engineering Department, University of South Florida, Tampa, FL 33620, USA.

Received: 30 December 2011 Accepted: 20 December 2012

Published: 5 January 2013

\section{References}

1. EIA: Annual Energy Review 2009. Washington DC: US Dept. Energy; 2009:446

2. Quadrelli R, Peterson S: The energy-climate challenge: Recent trends in $\mathrm{CO}_{2}$ emissions from fuel combustion. Energy Policy 2007, 35:5938-5952.

3. Wigmosta MS, Coleman AM, Skaggs RJ, Huesemann MH, Lane LJ: National microalgae biofuel production potential and resource demand. Water Resour Res 2011, 47:W0OH04.

4. Yusuf C: Biodiesel from microalgae. Biotechnol Adv 2007, 25:294-306.

5. Becker EW: Microalgae: biotechnology and microbiology. Cambridge, UK Cambridge University Press; 1994

6. Masojídek J, Torzillo G, Sven Erik J, Brian F: Mass Cultivation of Freshwater Microalgae, in Encyclopedia of Ecology. Oxford: Academic Press; 2008:2226-2235

7. Wiley $\mathrm{P}$, Brenneman $\mathrm{K}$, Jacobson A: Improved algal harvesting using suspended air flotation. Water Environ Res 2009, 81:702-708.

8. Bare WFR, Jones NB, Middlebrooks EJ: Algae removal using dissolved air flotation. Water Pollution Control Federation 1975, 47:153-169.

9. Barbosa MJGV: Microalgal photobioreactors: Scale-up and optimization. Wageningen, The Netherlands: Wageningen University; 2003:168.

10. Ferrell J, Sarisky-Reed V: National Algal Biofeuels Technology Roadmap. In US Dept. Energy, Office of Energy Efficiency and Renewable Energy, Biomass Program. Washington DC; 2010.

11. Shelef G: A Sukenik, and M Gree, Microalgae Harvesting and Processing: A Literature Review. Editor: DOE; 1984.

12. Stephens E, Ross IL, Mussgnug JH, Wagner LD, Borowitzka MA, Posten C, Kruse $\mathrm{O}$, Hankamer B: Future prospects of microalgal biofuel production systems. Trends Plant Sci 2010, 15:554-564.

13. Gouveia L: Microalgae as a Feedstock for Biofuels, in Microalgae as a Feedstock for Biofuels. Springer Berlin: GDR; 2011:1-69.

14. Pittman JK, Dean AP, Osundeko O: The potential of sustainable algal biofuel production using wastewater resources. Bioresour Technol 2011, 102:17-25.

15. Campbell PK, Beer T, Batten D: Life cycle assessment of biodiesel production from microalgae in ponds. Bioresour Technol 2011, 102:50-56

16. Sturm BSM, Lamer SL: An energy evaluation of coupling nutrient removal from wastewater with algal biomass production. Applied Energy 2011, 88:3499-3506

17. Eaton AD, Franson MAH, A American Public Health, A American Water Works, and F Water Environment: Standard methods for the examination of water \& wastewater. Washington DC: American Public Health Association; 2005 .
18. Bligh EG, Dyer WJ: A rapid method of total lipid extraction and purification. Can J Biochem Physiol 1959, 37:911-917.

19. Woertz I, Feffer A, Lundquist T, Nelson Y: Algae grown on dairy and municipal wastewater for simultaneous nutrient removal and lipid production for biofuel feedstock. SCE 2009, 135:1115-1122.

20. Li Y, Chen Y-F, Chen P, Min M, Zhou W, Martinez B, Zhu J, Roger R: Characterization of a microalga Chlorella sp. well adapted to highly concentrated municipal wastewater for nutrient removal and biodiesel production. Bioresour Technol 2011, 102:5138-5144.

21. Zhou W, Li Y, Min M, Hu B, Zhang H, Ma X, Li L, Cheng Y, Chen P, Ruan R: Growing wastewater-born microalga Auxenochlorella protothecoides UMN280 on concentrated municipal wastewater for simultaneous nutrient removal and energy feedstock production. Applied Energy 2012, 98:433-440.

22. Illman AM, Scragg AH, Shales SW: Increase in Chlorella strains calorific values when grown in low nitrogen medium. Enzyme Microb Technol 2000, 27:631-635

23. Frac M, Jezierska-Tys $\mathrm{S}$, Tys J: Microalgae for biofuels production and environmental applications. A review. African Journal of Biotechnology 2010, 9:9227-9236.

24. Richmond A: Principles for attaining maximal microalgal productivity in photobioreactors: an overview. Hydrobiologia 2004, 512:33-37.

25. Richmond A, Zou N: Efficient utilisation of high photon irradiance for mass production of photoautotrophic micro-organisms. J Appl Phycol 1999, 11:123-127.

26. Qiang H, Richmond A: Productivity and photosynthetic efficiency of Spirulina platensis as affected by light intensity, algal density and rate of mixing in a flat plate photobioreactor. J Appl Phycol 1996, 8:139-145.

27. Cuaresma M, Janssen M, Vílchez C, Wijfels RH: Horizontal or vertical photobioreactors? How to improve microalgae photosynthetic efficiency. Bioresour Technol 2011, 102:5129-5137.

28. Laws EA, Taguchi S, Hirata J, Pang L: Optimization of microalgal production in a shallow outdoor flume. Biotechnol Bioeng 1988, 32:140-147

29. Craggs RJ, Heubeck S, Lundquist TJ, Benemann JR: Algal biofuels from wastewater treatment high rate algal ponds. Water Sci Technol 2011 63:660-665.

30. Park JBK, Craggs RJ, Shilton AN: Wastewater treatment high rate algal ponds for biofuel production. Bioresour Technol 2011, 102:35-42

31. Ebeling JM, Timmons MB, Bisogni JJ: Engineering analysis of the stoichiometry of photoautotrophic, autotrophic, and heterotrophic removal of ammonia-nitrogen in aquaculture systems. Aquaculture 2006, 257:346-358.

32. Stumm W, Morgan JJ: Aquatic chemistry: chemical equilibria and rates in natural waters.: Wiley; 1996

33. Sialve B, Bernet N, Bernard O: Anaerobic digestion of microalgae as a necessary step to make microalgal biodiesel sustainable. Biotechnol Adv 2009, 27:409-416.

34. Ali Y, Hanna MA: Alternative diesel fuels from vegetable oils. Bioresour Technol 1994, 50:153-163.

35. Rittmann BE, McCarty PL: Environmental biotechnology: principles and applications:: McGraw-Hill; 2001

36. Yuan X, Wang M, Park C, Sahu AK, Ergas SJ: Microalgae growth using high strength wastewater followed by anaerobic co-digestion. Water Environ Res 2012, 84:396-404.

37. Chen Y, Cheng JJ, Creamer KS: Inhibition of anaerobic digestion process: A review. Bioresour Technol 2008, 99:4044-4064.

doi:10.1186/2046-9063-9-2

Cite this article as: Dalrymple et al:: Wastewater use in algae production for generation of renewable resources: a review and preliminary results. Aquatic Biosystems 2013 9:2. 